European journal of American studies

Special Issue: Spectacle and Spectatorship in American Culture

The Theatre of Revolution Transforms Spectators into Political Actors: Performance as Political Engagement in the Transnational Counterculture

Andrew Hannon

CpenEdition

Journals

Electronic version

URL: https://journals.openedition.org/ejas/15488

DOI: $10.4000 /$ ejas. 15488

ISSN: 1991-9336

Publisher

European Association for American Studies

Electronic reference

Andrew Hannon, "The Theatre of Revolution Transforms Spectators into Political Actors: Performance as Political Engagement in the Transnational Counterculture", European journal of American studies [Online], 14-4 | 2019, Online since 12 December 2019, connection on 08 July 2021. URL: http:// journals.openedition.org/ejas/15488 ; DOI: https://doi.org/10.4000/ejas.15488

This text was automatically generated on 8 July 2021

Creative Commons License 


\title{
The Theatre of Revolution Transforms Spectators into Political Actors: Performance as Political Engagement in the Transnational Counterculture
}

\author{
Andrew Hannon
}

"Do you honestly believe that a gentleman can amuse himself in Soho?"

- Guy Debord ${ }^{1}$

\section{Introduction}

1 OZ Magazine, the premier British sixties psychedelic magazine from 1967 to 1973, was widely influential. ${ }^{2}$ Its origins and development by Australians Richard Neville and Martin Sharp and British publisher John Wilcock provide a uniquely intersectional historical moment in which arts, music, and radical politics came together into a single formation. Underappreciated in its significance, the story of $O Z$, and most especially its influence by and spread of the ideas of the American anarchist artists and activists the San Francisco Diggers, illustrates two important elements of the 1960s counterculture. First, it demonstrates the connection between political and cultural ideas, techniques, and actors, a connection often occluded both at the time and in scholarship on the era, which has insisted on seeing politics and culture as separate. Secondly, the threads and moments of influence and connection embodied by $\mathrm{OZ}$ and its founders contribute to the growing body of scholarship examining the counterculture as a transnational entity, and, as did its members, looking beyond the limitations imposed by national (and academic) boundaries.

2 National borders and a focus on traditional politics produce a lacuna, a blind spot, obscuring deeply important connections that fail to fit within preconceived categories and narratives of the era. The true impact of insurgent ideas coming from these 
countercultural groups and cultural producers can only be appreciated and understood within their own terms and beyond the unnecessarily limiting boundaries-both national and disciplinary-within which we find ourselves constrained. Historian of the 1960s John McMillian reminds us that "the movement" of the Sixties and Seventies is best understood as a "constellation of social protest activity," and it is within this framework that it is most important to understand $O Z$ and the anarchist activists of their cultural and political formation. ${ }^{3}$ Cultural artefacts such as pop songs and underground magazines give us a sense of the affective register of the moment, a feeling for the zeitgeist of rebellion, and a way to understand the substantive meaning of sentiments such as "there was music in the cafes at night," as voice of a generation Bob Dylan reminds us, "and revolution in the air."

3 Theories of the Spectacle have emphasized the use of popular culture to pacify people, to turn them into passive observers of the troubling conditions around them. OZ, which published articles by Americans and reports on the American pop demimonde, would be the vector for the revival of a part of British radical history-the founding of a Hyde Park branch of the American Anarchist group the Diggers. ${ }^{5} \mathrm{~A}$ publication that started as a Sydney undergraduate humor magazine and a group of stoned actors are the kinds of cultural products and producers that are often seen as typifying the pacifying spectacle of empty performative pop-as just so many bread and circuses. And yet, as this history traces, we find these cultural workers radicalized by the state response to their art, so much so that they embraced anarchist avant-garde politics, to differing degrees of success. We see in them how culture strikes back against hegemony and pacification. It contains the tools for mobilization, for counter-movements. As American political scientist James C. Scott illustrates, when you see like a state, every joke is a threat, every stage a platform. ${ }^{6}$ In Australia, the United Kingdom, and the United States the state treated these groups as a grave threat to order. These disparate groups found ideology in common to understand and interpret their experiences. They could only do so after developing a culture in common.

\title{
2. Cultures in Common
}

\author{
"Man, we're all the same cats, we're all the same schmuck-the President, me, you, \\ every putz..." \\ -Lenny Bruce ${ }^{7}$
}

4 While the story of $O Z$ and the Diggers begins in Australia in 1963 with a humor magazine, it soon spreads to blur the boundaries between politics and culture and show the transnational reach of countercultural ideas. As university students in Sydney, Martin Sharp and Richard Neville published a juvenile humor magazine, a contemporary of the infamous American undergraduate National Lampoon. As seen in the example of Figure 1, Neville and Sharp's first magazine parodied the powerful and poked fun at conformity and propriety while celebrating humor and marijuana. 


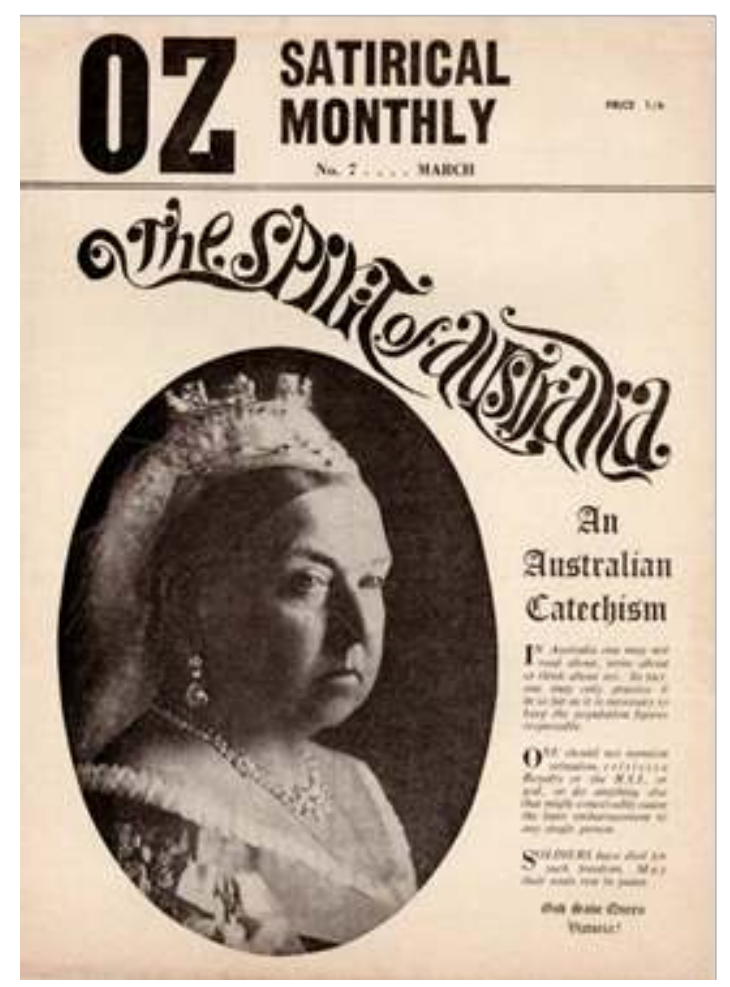

Figure 1: A page from Richard Neville and Martin Sharp's university magazine

In the stiff conservative culture of Australia in the 1950s and 1960s, these values provoked the authorities and resulted in obscenity charges. This trial, although settled in Neville and Sharp's favor, was to be only the first clash with obscenity law. ${ }^{8}$

Under these charges, Sharp and Neville found themselves having become inadvertently political actors in Australia. Through the obscenity trial in Australia and then another once they had moved to London and founded $O Z$ Magazine, Neville and Sharp overturned Victorian-era censorship laws that had their origins in colonial practices and the maintenance of the status quo. They may not have thought of their cultural production initially in political terms but, like many of their countercultural cohort, they quickly learnt that their seemingly empty cultural signifiers elicited a political response. This response was in itself radicalising. They were not advocating for candidates, for issues, or for people to vote or participate in government. In all of those areas they were just being mildly critical and "taking the piss." Those are actions that traditional political theorists and traditional political historians like to dismiss as apolitical, but we see here what is missed in that dismissal. ${ }^{9}$

Historian Michael Kramer has used the term "Woodstock Transnational" to help us see what transnational hippie identity in its proto-form meant to people who later had a lot in common. ${ }^{10}$ Initially, they had that culture in common because of the transnational reach of oppositional culture. Neville and Sharp were shaped by the same cultural influences as American proto-hippies. They too listened to Lenny Bruce records-albeit prohibited ones smuggled into Australia by Neville's uncle. Their magazine shared a sensibility with Paul Krassner's The Realist, seen in Figure 2. 


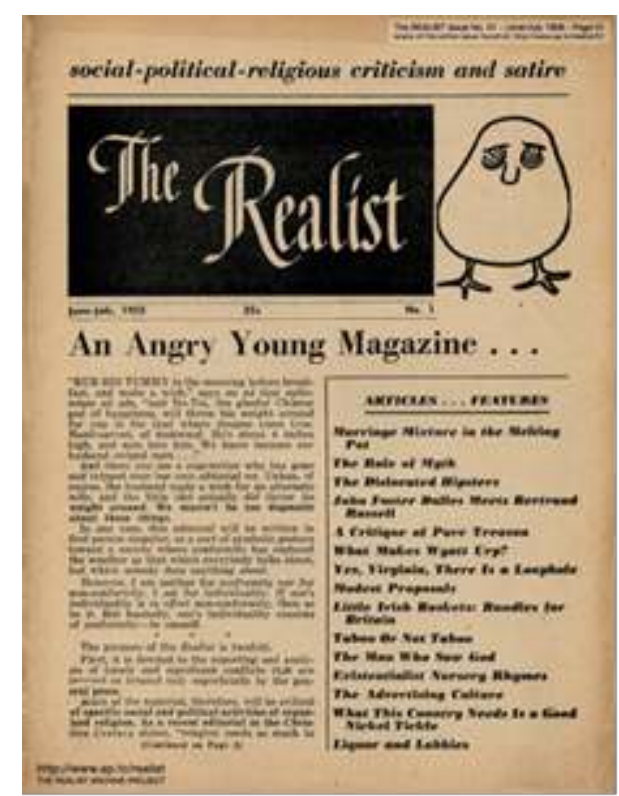

Figure 2: Paul Krassner's humor magazine The Realist

8 In one of many examples running through this narrative of the state politicizing culture through a restrictive and censoring response to cultural actors and products, both Krassner and the $\mathrm{OZ}$ founders were deeply impacted by both the work and the persecution of Bruce, the legendarily subversive comic. Krassner was a great admirer of Bruce, and had been dismayed by the changes he saw in Bruce's work as he was repeatedly harassed in the United States. As he was banned from stages and arrested on obscenity charges, his career began to spiral downwards.

Following this harassment in his home country, Bruce went on an Australian tour, where his performances were frequently censored and cancelled by the police. Following their own censorship while running their humor magazine at Sydney University, Neville and Sharp were hired by The Mirror, a newspaper owned by infamous publisher Rupert Murdoch, an Australian who later bought British citizenship. Murdoch, who was just beginning to create the media empire that would culminate in the foundation of the influential American conservative outlet Fox News, was amused by the $O Z$ founders' combative stance towards the state. When working at the paper, Neville found out about Bruce's Australian tour and contacted Bruce's agent to arrange for the comic to perform at Sydney University. That show was canceled, after which Bruce's agent called Neville asking him to check on the comic, who was morose in response to the cancelation. Neville found Bruce, who was sick from a heroin overdose. ${ }^{11}$

While $\mathrm{OZ}$ would go on to become an important voice of the countercultural media, it was the mainstream press that served as a medium through which alternative ideas echoed and became a source of influence for Neville and Sharp. It spread news of the emerging counterculture, with almost every mass media outlet carrying some variation of "The Summer of Love" narrative of wild hippies acting out-enjoying a bit of sex, drugs, and rock and roll (and always with an undercurrent of revolution). Even sympathetic articles paired voyeuristic exploitation with an element of moral panic, seen in examples such as writer Hunter S. Thompson's essay on the "Hashbury" for the New York Times Magazine, musician Loudon Wainwright's column for Life describing what he termed "The Strange New Love Land of the Hippies," and investigative TV 
segments such as the CBC's "Toronto's Yorkville: Hippie Haven," featuring future science-fiction writer William Gibson as the native informant. ${ }^{12}$ These pieces circulated far beyond what one might anticipate their audiences to be, exercising a truly transnational reach. They served as a nearly irresistible siren song to readers with an inchoate oppositional identity.

In 1966, Neville and Sharp read mainstream US publication Time Magazine's coverage of "Swinging London" in an article entitled, "Great Britain: You Can Walk Across It On the Grass." 13 "Swinging London," like "The Summer of Love," was an organic happening, an authentic community, transformed into a plastic pop culture commodity, but the reporting on it could still carry enough information for oppositional readers to lead to the unexpected mushrooming of activism. ${ }^{14}$ Aimed at a presumed audience of middleclass professionals and working people, the piece was of a genre of moral panic about youth culture, treating youth subcultures and the individuals that composed them as profoundly other. But for those that already understood themselves as other, and envisioned their identities and ways of being as counter to the hegemonic culture of the moment, these articles carried a different message. To borrow a phrase from cultural theorist Stuart Hall, although encoded with an element of official disapproval, some readers decoded articles on the strange new happenings with a decidedly different valence.

For Neville and Sharp, this article did not produce a sense of disapproval or distancing from the emerging hip culture. Instead, they wanted to be a part of it. They made their way up the Hippie Trail through Southeast Asia, chasing the promise of popular culture, of other scenes and new situations alive with a culture and politics at odds with what they saw as the establishment conservative values they had encountered in Australia. Neville covered their trek in dispatches for the Sydney Morning Herald, with accompanying cartoons by Sharp until the pair separated after Thailand. ${ }^{15}$ Sharp preceded Neville to London, while Neville pursued a longer overland route through Nepal, Afghanistan, Iran, Turkey, and continental Europe before travelling from Amsterdam to join Sharp in London. There, these Australian transplants encountered a complex hip scene that was in the process of unfolding.

It is difficult to convey the degree of cultural change in words alone. Luckily, visual documentation of that change in the moment was captured. This mid-sixties protohippie demimonde is illustrated in photographs by John "Hoppy" Hopkins. ${ }^{16}$ In Hopkins' photograph entitled "Marijuana Boys," (Figure 3) we see a man in mackinaw and trousers buying a bag of marijuana on the streets.

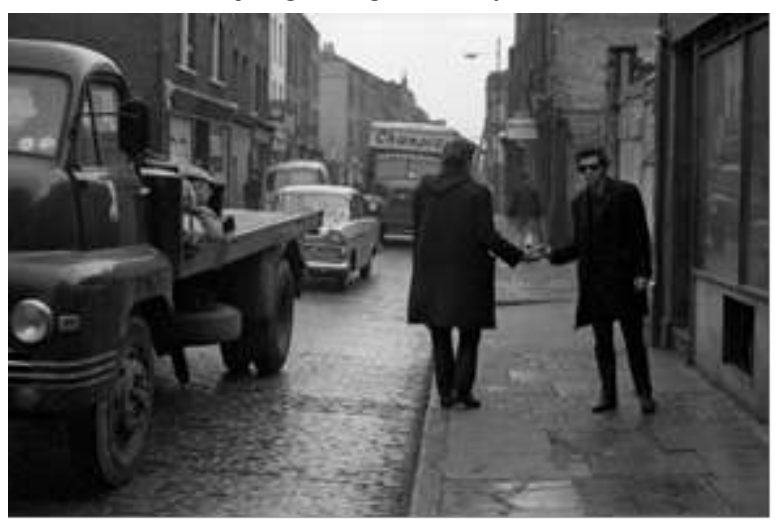

Figure 3: "Marijuana Boys" by John Hopkins 
In "Joint Factory," (Figure 4), we see a group of people cutting up an ounce of marijuana to roll into joints, with not a single man with hair longer than his ears, nor a woman with hair shorter than her chin, all in unremarkable traditional British clothing. Hopkins was catching a moment before the culture changed.

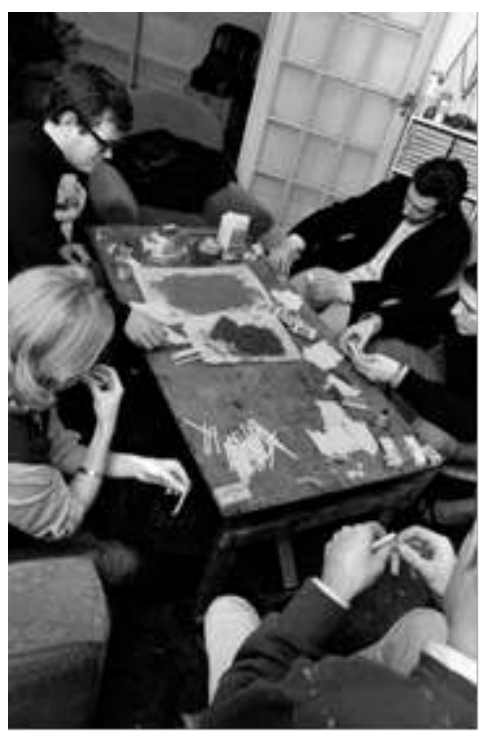

Figure 4: "Joint Factory" by John Hopkins

This is what London looked like-even freak, bohemian, drug-using London, before the changes that $\mathrm{OZ}$ embodied. A few years later, all of the set-dressing and costumery of that scene would be different. There would be a stack of Day-Glo OZ magazines in the corner, Cream blasting on the stereo, long hair, peasant tops (from Eastern Europe), bold fabric patterns from Africa and India, and perhaps a guru shrine-and certainly a book of yoga poses. This was the detritus of the hippie trail. In a moment of the shrinking of the national boundaries of the British Empire, suddenly all of these cultural objects-each individually a part of a local history, context, and culture-were taken up and used to signify a culture in common that transcended those boundaries.

This proto-hippie set of signifiers was, importantly, transnational, providing connection points through music, drugs, and clothing to those of a shared interest. To some, it constituted an irresistible siren song that pulled them away from their unexamined lives. In politics, anarchist artist Ben Morea and anarchist theorist Murray Bookchin understood these bonds as necessary for "affinity groups." ${ }^{17}$ More casually, one might refer to this as just being fans. Affordable records, cheap shipping, and postwar surplus clothing allowed youth on three continents to share culture in common, to forge new kinds of old bonds. Solidarity and shared affect are characteristics of tribal fandom. Culture in common allowed radical actors such as Sharp and Neville to "find the others," as Timothy Leary's famous phrase asserted. Having that culture lightly washed through the exotic other of another nation's popular culture could be validating of forgotten ideas.

\section{The Siren Song of Popular Culture}

“There's no doubt England is on the verge of its most exciting cultural revolution for many years. Everything is starting to come together: an exciting winter is 
coming up. Many more of America's social and cultural guerrillas have had their effect."

-John Wilcock ${ }^{18}$

While OZ Magazine was brought into being through the transnational transmission of countercultural ideas in both the mainstream and the underground press, the magazine itself would further act as conduit not only for ideas and ways of being, but for actual identities and group formations. Neville and Sharp's magazine took up and broadcast the unique mode of performative politics of the San Francisco Diggers, a group of anarchist activists who used performance to enact and communicate their critique of capitalism and social control. In doing so, $O Z$ itself called into being a London-based Diggers organization.

As I have asserted elsewhere, the magazine articulated a politics to which searching hippies, following the vibration of oppositional culture, could attach themselves. ${ }^{19} \mathrm{~A}$ inauthentic moral panic called an authentic community into being. The historical English Diggers appealed in America because of the shared heritage of English and American history, but also because their foreignness kept them outside of Cold Warinfluenced scuffles over radicalism. Those Diggers were pastoral communalists in the period of the English Revolution. They were known for spontaneously collectivizing gentry lands back to common uses through digging. We can see these transnational cultural vibrations in the meaning and purpose that the New Left Review served for C. Wright Mills, and, as British sociologist Paul Gilroy has explored, how Jimi Hendrix was revalidated by going to Britain..$^{20}$ It may seem odd to influence the work that national boundaries do in the work of adapting culture in an assertion of transnationalism. However, it is a constitutive part thereof, as cultural theorist Raymond Williams helps us see. ${ }^{21}$ The consumers of this culture, the producers, understood themselves (to varying degrees) as part of a formation beyond national boundaries.

Picture 3. Sharp and Neville's influence is attributable, in part, to Sharp's participation in a key site of popular music. Sharp fallen into conversation with a long-haired guitarist at a bar shortly after his travels along the Hippie Trail. Looking for lyrics for a piece of music, the guitarist took with him a poem that Sharp's had composed during his trip, written on a napkin. The poem became the song "Tales of Brave Ulysses," the B-side to Cream and guitarist Eric Clapton's hit single "Strange Brew." 22 Sharp also created the distinctive psychedelic art for the cover of Cream's immensely popular album Disraeli Gears (Figure 5), elevating him to new heights within London's hip community, a fusing of avant-garde culture and politics for which the London of 1967 was longing. 


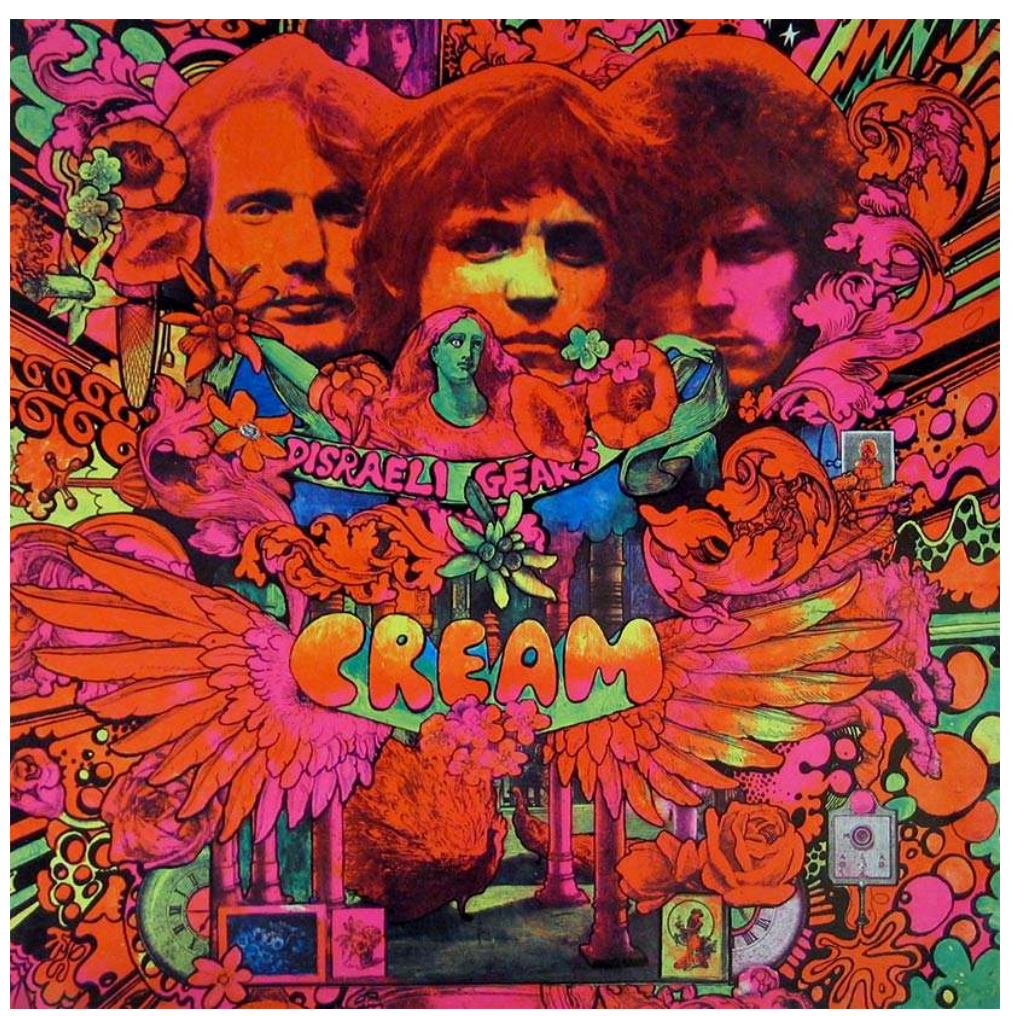

Figure 5: Martin Sharp illustrated album cover for Cream's "Disraeli Gears"

Sharp had arrived in London without much direction. He had been following Neville's choice in destination. Neville's older sister, novelist and playwright Jill Neville, had proceeded the men to England, a path also blazed by fellow Australian Germaine Greer, who would shortly write for $O Z$ under the nom de plume "Dr. G." The men were, after a fashion, tagging along behind Jill, and Neville initially crashed with his sister. When Neville joined Sharp in London a few months later they revived OZ, seen in Figure 6, using what can be mistaken as the superficiality of aesthetics, popular culture, and parody to transmit powerful ideas about resistance to hegemonic modes of being and action.

21 The tools through which the magazine transmitted radical ideas included a parody of exactly the same kind of pop puff piece that had drawn them to London. Using the selfsame moralizing language usually directed at marginalized subcultures, "The Truth about the Great Alf Conspiracy/Plant a Flower Child," (published in July 1967) described the most horrifying thing in the world: people going to work..$^{23}$ Through defamiliarizing the mundane everyday activities of workaday commuter life, this piece of satire poked sly fun at mainstream society, demonstrating the arbitrariness of norms and social conventions while simultaneously making an implicit argument through cultural production. ${ }^{24}$ 


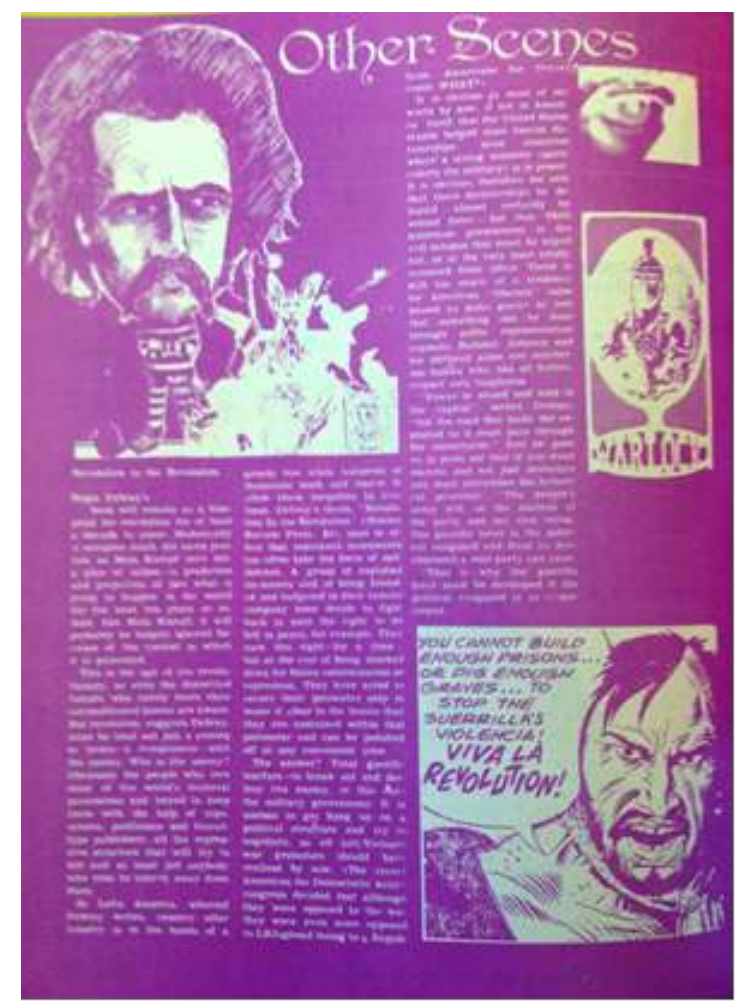

Figure 6: Martin Sharp and Richard Neville's OZ Magazine

$\mathrm{OZ}$ also ran pieces from other outlets of the underground press. Early on, articles were more appropriated than officially republished. This was a fairly common practice at the time, particularly in newly founded publications. Content from other presses ran unattributed as original reportage. This practice was formalized in the emergence of the Underground Press Syndicate. In the process, these publications were transformed by the graphic design sensibility that fused avant-garde politics with avant-garde art. The articles were not merely reprinted. They were occasionally radically edited and always subject to significant reformatting, often with purposeful experimentation in typography and layout. This process went beyond mere editing and even occasionally approached the violence of a Burroughs-esque cut up (named for American writer William S. Burroughs), in which the original article's text was cut into separate paragraphs or sentences and rearranged. In their reformatting and reconstitution, the artwork and articles were remixed, with their meaning recontextualized. They became examples of bricolage.

One important example of this practice was the article that would ultimately bring the San Francisco Diggers, a group of actors turned anarchist activists, to the attention of $\mathrm{OZ}$ and its London readership. Originally published in the March 1967 issue of Ramparts, an influential American radical magazine, reporter Warren Hinckle's "Social History of the Hippies" article ran in Issue 3 of $O Z$ under the title, "Will the Real Frodo Baggins Please Stand Up?," referring to the hobbit hero of J.R.R. Tolkien's The Lord of the Rings. ${ }^{25}$ Hinckle's original reporting followed a series of moral panic articles that treated the Haight-Ashbury scene as a trivialized youth craze, and pointed to something real and political in what had been dismissed as a pop culture fad.

While the commodifying gaze of capital was turned on youth culture and focused on turning rebellion into money, Hinckle's piece documented the pressures to transform, 
co-opt and commodify an authentic community into "plastic hippies," but it also presented the denizens of Haight-Ashbury as talking back to that privileged gaze of power. Through wrestling with what-if any-political valence of the counterculture had served as inspiration to British hippies, Hinckle returned the name and methods of enaction of the Diggers to the United Kingdom. He declared the importance and seriousness of the moment others had trivialised and posited prominent and influential member and actor Emmett Grogan and the rest of the Diggers as heroes. ${ }^{26} \mathrm{He}$ treated the "weird dancing and light shows," as annoyed English reader John Whiteman phrased it in a letter to the editor in $O Z$, not as a distraction from politics but as an important front of radical struggle. ${ }^{27}$ Transmitted through cultural artefacts, this piece contained a scheme for flipping the script in a play for power and control in hip communities.

As described by Hinckle, the actions and ideas of the San Francisco Diggers spoke to the desire for rebellion and revolution in the readers and writers of OZ. OZ's intimacy with the cream of hip London society provided important social cachet to their endorsement of the Diggers within Britain, and OZ's endorsement of the Diggers made this inchoate positioning of "hipness" into a specific radical politics.

These San Francisco activists had taken their name from seventeenth-century English radicals. Responding to the enclosure of the common lands of the nation, those original Diggers had seized the lands of the aristocracy as "a common treasury for all" and farmed it for mutual aid. The Diggers of Haight-Ashbury in the 1960s took their anarchist philosophy of a post-scarcity world and combined it with the theatrical training of the group's most famous members-Emmett Grogan, Peter Coyote, and radical playwright Peter Berg-to act as if the revolution was already over and they had won. Reflecting powerful new modes of political engagement based in resistance to hegemonic power on the level of individual performance, yet also connecting to the preoccupations of their namesakes, the Diggers provided free food to the daily onslaught of incoming hippies in the Panhandle section of San Francisco's Golden Gate Park, set up free stores with supplies of the repurposed waste of consumerism, and built free crash pads and clinics. While the Diggers are less well known today than their splinter group the Yippies (founded by Abbie Hoffman and originally known as the New York Diggers), their major actions, including the Free Stores and Free Clinics and their mock-funeral marches for the "Death of "Hippie" and "Death of Money" received significant press attention within the moment.

Inspired by these actors and activists, British publisher John Wilcock called for a London Diggers group to come into being in his October $1967 \mathrm{OZ}$ article, entitled "Blueprint for a Beautiful Community. ${ }^{28}$ One of the founders of the Village Voice and onetime participant in psychedelic researcher Timothy Leary's psilocybin experiments, Wilcock pulled no punches in his enthusiastic endorsement of the Diggers. ${ }^{29}$ In the face of recuperation and commodification of the type that characterized the emergence of hip communities in Greenwich Village, Haight-Ashbury, and Los Angeles' FairfaxMelrose district, Wilcock wondered what was to be done. ${ }^{30}$ "How can such a community be strengthened and structured?," he asked rhetorically. In response, Wilcock offered the Diggers as a model, an authentic community response posited in opposition to the plastic and inauthentic attempt to commercialize 'the love revolution,' their performative political techniques providing a ready-made way to fight back against cultural appropriation. The Diggers were the blueprint for a beautiful community. 
itself would move from covering the Diggers to identifying itself as part of the Digger movement, as Issue 9 in 1968 announced the founding of a London Diggers group in Hyde Park. ${ }^{31}$ As seen in Figure 7, the magazine ran ads for the Diggers, and included itself as part of that formation. Wilcock's endorsement provided a cohesion point for articulation of an anarchic oppositional politics, a transatlantic circulation of radical techne through psychedelic popular culture. As the founding of the London Diggers demonstrated the transnational presence and international significance of a radical avant-garde oppositional culture, the theatrical techniques of the San Francisco Diggers that inspired them-such as the free store, free food and street occupationsdramatically expanded the repertoire of radical social protest.

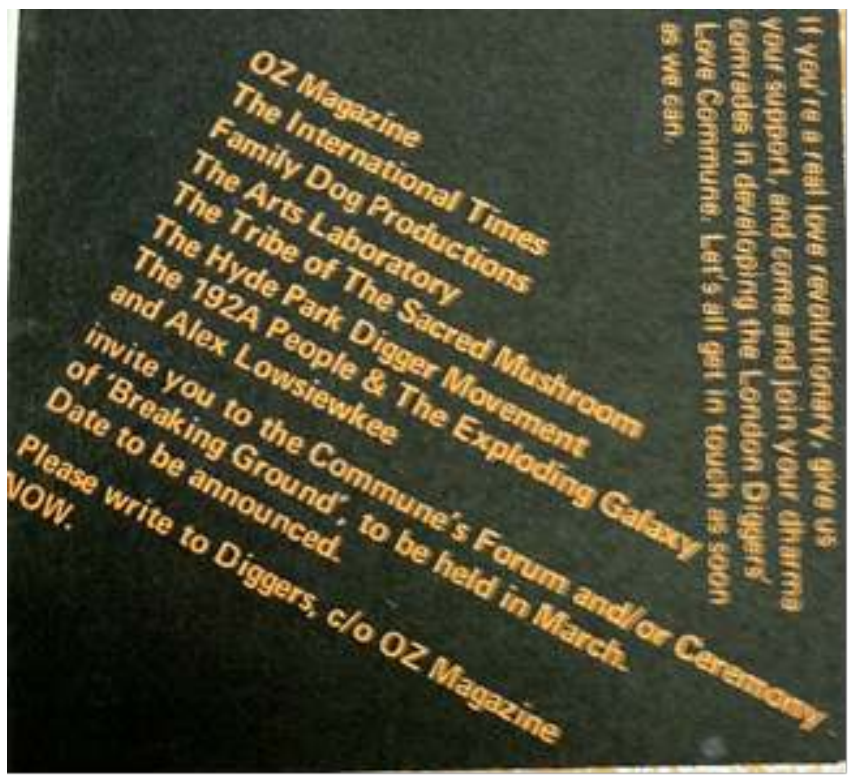

Figure 7: Ad for the Diggers in OZ Magazine

"OZ has been inundated with letters from readers responding to the article in $O Z$ 9," the editors triumphantly wrote of the response to a call for a Diggers group in London. In The Vietnam Issue they announced a formational meeting (referred to the Forum in the quote below) and identified an initial group, stating that "an interim group of London Diggers has been going ahead with the arrangements for staging the Forum, and setting up the contacts necessary to get a successful community into action straight after." ${ }_{32}$ The forum was planned at the Anti University, a parallel popular institution of knowledge production similar to the contemporary New York Free University. The forum drew upon a wide range of radical thought, and included Americans Judith Malina and Julian Beck, touring Europe with the Living Theatre, and theorist of the counterculture Theodore Roszak, who presented an early version of his seminal essay The Making of a Counter Culture there. The forum was successful in generating a mushrooming of enthusiasm for a playful radical politics, but could not quite overcome the inherent limitations to coordinating a transnational cultural formation, and activities between London- and US-based groups remained inconsistent. As will be discussed in the next section, the transfer of radical ideas through culture was often more successful than planned meetings.

The Hyde Park Diggers organized squats and crash pads, free food and free stores, and political and cultural forums. ${ }^{33}$ They fought against the recuperation of hippie culture through asserting a specific militant radical identity in these actions at the same 
moment where hippie couture was being sold on the high street..$^{34}$ Most importantly, they maintained a counter-movement against the co-option and commodification of their alternative and occasionally insurgent subculture. In this, they echoed their namesakes' fight against enclosure. They understood themselves as digging in to fight against the enclosure by consumerism of a cultural commons of rebellion. They insisted that, like the commons of the seventeenth century, their culture was a common treasury for all, and that its co-option was the contemporary equivalent of the enclosure movement. Coming from a popular culture derided for distracting from traditional values and history, the contemporary Diggers served as an entry point for radical history's return and an introduction to the concepts of post-scarcity economics. 35

31 As anarchists, members of the Diggers, whether of San Francisco's Haight-Ashbury or London's Hyde Park, had little use for nations or their international boundaries. They came to this conclusion culturally before they came to it politically. They shared a culture in common as members of an oppositional subculture, one that crossed borders and produced a different sort of imagined community-a community based upon common experience, aesthetic taste, and affective relationships. Cultural artefacts such as pop songs and performances of self-created a political consciousness. Before they could become Diggers, they were hippies. And in being hippies they found a new consciousness.

\section{A Missed Opportunity}

"“Cause they have made our British Empire

A better place for me and you

And this was their finest hour."

-The Kinks ${ }^{36}$

US-based and British Diggers remained loosely affiliated, and their actions uncoordinated. An encounter at Apple Records headquarters is one of the great missed opportunities of the 1960s and an almost heartbreaking and all-too-human squandered moment. A Christmas 1968 meeting between Neville and Digger founders Peter Coyote and Emmett Grogan was a disaster. In the uncomfortable commotion, Neville failed to realize that his heroes were there, finally present in the flesh, and he unfortunately mistook them for Hell's Angels on tour with the Grateful Dead. They were spouting anarchist post-scarcity philosophy, but they were also very taken with the recently legalized British medical heroin.

Neville begins his memoir Play Power with an anecdote about a Hell's Angel visiting the Beatles. This American captured Neville's attention, but a further connection was never made. '“Whenever you ring me,' he said, 'ask for Pete the Coyote.' And whenever I did, no one had ever heard of him," Neville recalled..$^{37}$ As the Beatles tried vainly to evict Coyote and his companions from their Savile Row headquarters, Coyote held forth on the coming economics of a post-scarcity world: "The cybernetic age entails a change in our frame of reference, man.... the digital computer is easing us into the electronic/ automotive age just as the steam engine pivoted into the Industrial Revolution." Coyote framed the issues of technological change and substance use to an audience of terrified Apple Music employees, Hell's Angels, and Ken Kesey and his ever-present microphone. Contrasting the folk response to the Industrial Revolution with the contemporary enthusiasm for altering consciousness, he said, "In those days it was gin. It flowed like 
water. Kids were suckled on it, societies campaigned against it. Now it's acid. LSD is for us what gin was for the Victorians. It lubricates our acceptance of a new age[.]" 38 This oddly prescient description of the emerging Bay Area computer sector came from what appeared to be a Hell's Angel who shortly thereafter nodded out in the bathroom.

As we see in Figure 8, OZ had run a provocative full-page spread of a biker with a woman in his lap, peeking over his shoulder in clothing that suggested both the cultural menace of BDSM and that of fascist street gangs. Seen next to the Coyote of that era, the confusion is somewhat understandable. Coyote was indeed in England in 1968 on the Grateful Dead's informal tour. ${ }^{39}$

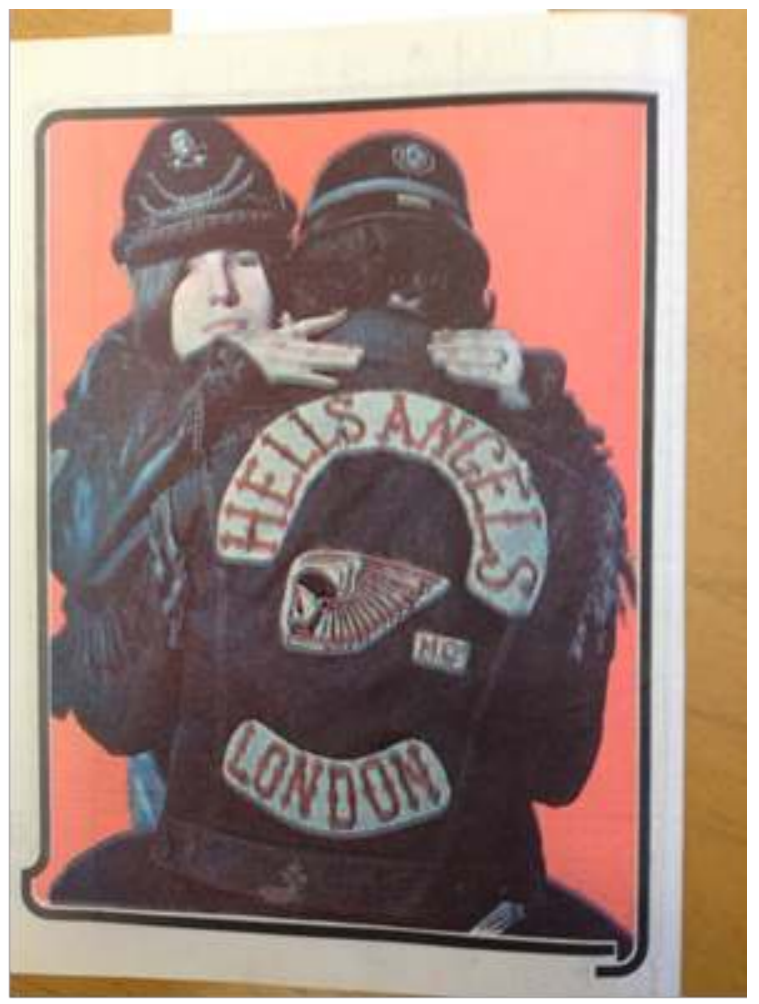

Figure 8: Image of Hells Angel in OZ Magazine

The impulse for the mission was for Coyote and a few Angels visiting London to meet the Beatles, along with the Dead. The Grateful Dead sent a crew to London in the winter of 1968-1969. The Dead themselves joined the expedition between a January 5, 1969 show at the Fillmore West in San Francisco and a January 17 show at the Robertson Gym in Santa Barbara, California..$^{40}$ The Dead broke briefly from their never-ending tour schedule to travel to England to meet (and assess) the Beatles. "In the winter of 1968-9, I was invited on a trip to England by the Grateful Dead, to accompany Emmett, Paula McCoy, Ken Kesey and some of his Merry Pranksters, and Hell's Angels [sic] Sweet William and Pete Knell," Peter Coyote recalls. "The Dead had mounted a cultural mission to 'check out' the Beatles and determine if they were as socially inventive and progressive as their music suggested." 41

The London Run, as the incident would become infamously known as in Deadhead history, was indeed a mission, "although a mission to what was never entirely clear," quips Grateful Dead official historian Dennis McNally. The political history has been lost as the politics of the counterculture has been effaced. McNally quotes Kesey referring to it as "a kind of cultural lend-lease, heads across the water and all that." ${ }^{42} \mathrm{At}$ 
this time, Kesey had made the transition from lauded author to LSD acolyte and countercultural celebrity, hiring the Dead as the house band of his Acid Test parties. To McNally, writing the oral history of the Dead thirty years later, the reason for this bizarre and intriguing confluence of pop musicians, political activists, and cultural figures is confusing, particularly following a decade of Sixties publications that insist that those histories, of the political and the cultural, and those formations, of the New Left and the Counterculture, were antagonistic, not overlapping. This was the dominant trope in the historiography of the era throughout the 1980s and 1990s.

By the time Peter Coyote published his memoir Sleeping Where I Fall in 1999, this narrative of difference would be so dominant that he would have to add an explanatory note to preface the incident. "I realized that it sounds arrogant to assert that a famous rock band might enhance its status by association with an impoverished band of anarchists," Coyote humbly offered, "but the social climate in the sixties was nothing if not complex." "43 This complexity has been effaced throughout the intervening decades and has only lately been recaptured. The Dead "were now somewhat removed from the cutting edge and hardscrabble life of the streets, the theatre where the Diggers excelled. The Diggers, like our counterparts in Holland, the Provos, were internationally known within the counterculture at this point, and bringing us along would reinforce the Dead's bona fides, 'sending a signal' in the parlance of politics, about the Dead's affiliation. At the same time it would afford the Dead access to our analysis and social inventiveness." ${ }^{44}$ For prominent Digger Emmett Grogan it represented a return to London after a successful encounter with the French Situationists, a meeting that reflects the flow of ideas between cultural and political figures, as well as the interest in the theory of the spectacle amongst the Diggers and their compatriots. Figure 9 shows Guy Debord's signature on a pamphlet that he gave to Grogan. ${ }^{45}$

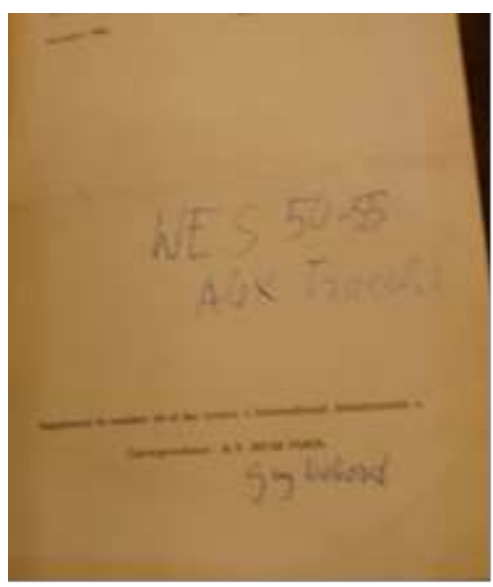

Figure 9: Guy Debord's signature on a pamphlet he gave to Emmett Grogan

\section{Conclusion: Transforming Spectators}

"The Times has just announced the projected demolition of the Chinese quarter in London. We protest against such moral ideas in town-planning, ideas which must obviously make England more boring than it has in recent years already become. The only pageants you have left are a coronation from time to time, an occasional royal marriage which seldom bears fruit; nothing else.

- Michéle Bernstein, Guy Debord, and Gil J. Wolman ${ }^{46}$ 
What can we learn of resisting the spectacle from exploring the relationship and paths of influence between two countercultural bodies: the London-based (and Australianfounded) OZ Magazine and the San Francisco Diggers? In the specific history of these groups and the spread of ideas between and from them we see the limitations of examining both the counterculture and the 1960s as a whole in ways that are rigidly demarcated by national boundaries and by distinctions between cultural and political acts and actors. $O Z$ and the Diggers were a transnational formation in that it constituted groups that moved easily across borders, but much more importantly in its conception of itself. Countercultural groups did not think of themselves in terms of national outposts of an international organization. Rather, they considered themselves as a collective with local constituents, part of an informal network to whom borders were of limited consequence. International borders can obscure the true impact and import of these transnational formations. Their culture crossed borders through airwaves, cultures in common, and imagined communities of shared experience.

The geographic reach of this transnational formation was broader than currently imagined. The Diggers of London serve to locate their American counterparts within the larger constellation of social protest organizations constituting the Movement. ${ }^{47}$ We can best understand that constellation as a formation, to borrow Raymond Williams's term, of interconnected groups and people sharing a similar ideology or affective orientation. To do so is to see something occluded by the rigid boundarypatrolling of later imposed categories. An assessment of the legacies and influences of a mode of performative politics and delineation of the formation that practiced its mode of acting out would be incomplete without them. Their existence and accomplishments are of extreme importance when assessing the efficacy of this mode of political engagement and broadening our understanding of the modes of radical political action.

Digger techniques interjected agency into the process of population formation. They provided tools to assert agency into the definition of a subculture. They gave people ways to speak back as militant hippies and techniques for claiming and controlling the mediums of popular culture, most especially through the popular press. Rather than a monolithic, hegemonic, disciplining force, culture could be used to contest power. Digger techniques enabled actors and activists to momentarily seize control of the means of cultural production. It allowed them to speak back to narratives of moral panic and the exploitative gaze of what fellow transnational traveler, wanderer of the hippie trail, and anarchist political theorist Hakim Bey has termed the "blind Panopticon of consumer capitalism." ${ }^{48}$

41 These are valuable lessons to take in our current age. As poet, musician, and manager of 1960s rock group MC5 John Sinclair noted in a 2016 interview, the current US president is a reality television star, and issues of the pacifying disorientation of the spectacle are at the forefront as we drift toward emerging fascism. Under these circumstances, it is easy to see popular culture as a one-way street and become despondent about the domination of the senses. Theories of the spectacle have focused on the paralyzing and pacifying aspect of the consumption of popular culture. ${ }^{49}$ Authors such as Todd Gitlin and Thomas Frank blame the counterculture specifically for being a distraction from important political work of the time, and locate within that counterculture the reasons why this political work was undermined..$^{50}$ In later work, such as What's the Matter with Kansas?, Frank broadened that thesis into a wider critique of culture and culture industries, asserting again that culture is a distraction. ${ }^{51}$ As seen 
in Chris Hedges' more recent Empire of Illusion, this despair (a misreading of Gramscian pessimism) towards culture and its supposedly pacifying effects has been an ongoing concern amongst those on the left, let alone amongst conservatives. ${ }^{52}$ Yet those actors and activists found useful tools for turning the spectacle against itself within the medium of popular culture.

We understand the Sixties as a moment in which radical change seemed possible. The zeitgeist was one of revolution, and the barrier for everyday people to consider themselves a part of a larger movement and to act out to change the world was lower than it is in our present moment. That affective relationship to systems of power, those moments of what Italian political philosopher and Communist Party head Antonio Gramsci might call the triumph of the optimism of the will over the pessimism of the intellect, those feelings of the possibility of radical change are captured in, and even arguably produced by, cultural artefacts. Pop culture carries with it a significant weight of contemporary politics. Culture moves, and moves easily, across borders, carrying within it inherent issues of co-option, commodification, and recuperation. In the Sixties it carried an insurgent oppositional politics across national borders.

\section{NOTES}

1. Letter to the editor, included in The Situationists and the City, Tom McDonough, ed. (New York: Verso, 2009), 52.

2. An earlier iteration of this project was published as "Hippie is a Transnational Identity: Australian and American Countercultures and the London Oz," Australasian Journal of American Studies, 35, n. 2 (2016): 39-59. My thanks to that journal for permission to use images.

3. John Campbell McMillian, "You Didn't Have to Be There: Revisiting the New Left Consensus," in The New Left Revisited, McMillian and Paul Buhle, eds. (Philadelphia: Temple University Press, 2003),. 6.

4. Bob Dylan, Blood on the Tracks, LP (New York and Minneapolis: Columbia, 1975).

5. "Digger" in this context has dramatically different valences within American, British, and especially Australian contexts. Its polysemic meanings are explored later in this essay.

6. James C. Scott, Seeing Like a State (New Haven: Yale University Press, 1998).

7. Lenny Bruce, quoted in Richard Neville, Hippie Hippie Shake: The Dreams, the Trips, the Trials, the Love-Ins, the Screw Ups... the Sixties (Port Melbourne, Australia: William Heinemann Australia, 1995), 21.

8. Nearly a decade later, Neville and Sharpe would triumph over British censorship after a prolonged and expensive trial defending OZ issue 28: Schoolkids. Neville, Hippie Hippie Shake, 350-351.

9. See, for example, Todd Gitlin, The Sixties: Years of Hope, Days of Rage (New York: Bantam Books, 1987) and Thomas Frank, The Conquest of Cool: Business Culture, Counterculture, and the Rise of Hip Consumerism (Chicago: University of Chicago Press, 1987).

10. Michael J. Kramer, The Republic of Rock: Music and Citizenship in the Sixties Counterculture (New York: Oxford University Press, 2013). 
11. Neville, Hippie Hippie Shake, 21-23.

12. Both Thompson's and Wainwright's relationships to the subject they covered are fascinatingly complex, as they themselves would become as imbricated in the formation they were covering as Gibson was himself. Hunter S. Thompson, "The 'Hashbury' Is the Capital of the Hippies," New York Times Magazine, May 14, 1967, SM14; Loudon Wainwright, "The View From Here: The Strange New Love Land of the Hippies," Life, March 31, 1967, 14-15.; “Toronto's Yorkville: Hippie Haven," CBC Newsmagazine (Canada: CBC, September 4, 1967),

http://www.cbc.ca/archives/categories/society/youth/hippie-society-the-youthrebellion/yorkville-hippie-haven.html.

13. "London: The Swinging City/ Great Britain: You Can Walk Across It On the Grass," Time, April 15, 1966, http://content.time.com/time/magazine/

0,9263,7601660415,00.html.

14. Ibid.

15. Richard Neville, "The Youth of Singapore: Richard Neville and Cartoonist Martin Sharp Are on a World Tour, Hitch-Hiker Style," Sydney Morning Herald, May 14, 1966; Neville, "Hiking through Thailand," Sydney Morning Herald, May 27, 1966.

16. "Counterculture", Image gallery, Hoppyx.com, https://hoppyx.com/image-gallery/counterculture/

17. Murray Bookchin, Listen, Marxist! (New York: Anarchos, 1969).

18. John Wilcock, "Blueprint for a Beautiful Community," OZ, October 1967, Beinecke Rare Book and Manuscript Library, Yale University, New Haven, Connecticut, 28.

19. Andrew Hannon, "Hippie is a Transnational Identity: Australian and American Countercultures and

the London OZ," Australasian Journal of American Studies, 35:2 (2016): 39-59.

20. Paul Gilroy, Darker Than Blue: On the Moral Economies of Black Atlantic Culture (Cambridge, MA: Belknap Press, 2010).

21. Raymond Williams, Keywords: A Vocabulary of Culture and Society (New York: Oxford University Press, 1985).

22. "Tales of Brave Ulysses," lyrics by Martin Sharp, music by Eric Clapton. Cream, Strange Brew/Tales of Brave Ulysses, Single, 1967.

23. "Plant a Flower Child/The Truth about the Great Alf Conspiracy," OZ, July 1967, 1-2.

24. An act of defamiliarization perhaps inspired by the often defamiliarizing effects of LSD. The B-side to the fold-out issue is "Plant a Flower Child," an arresting neon purple photocollage of a topless flower child-assembled from a photo shoot during which Martin Sharp dosed Richard Neville with acid for the first time. Richard Neville, Hippie Hippie Shake,85-88.

25. Warren Hinckle, "Social History of the Hippies," Hinckle, "Will the Real Frodo Baggins Please Stand Up?"

26. Hinckle's piece resonated within explicitly political organizations, inspiring Paul Jacobs' glowing recommendation of the Diggers and their techniques and tactics in "A New Kind of Revolution?" Liberation, May 1967, 46.

27. John Whiteman, "Letter to the Editor," 2.

28. John Wilcock, "Report on First Taking Psilocybin." (New York, July 1961), Box 42, File 42.4, John Wilcock 1961 file, Timothy Leary Papers, New York Public Library, New York; Wilcock, “The Village Square by John Wilcock, 'A Visit to Other Worlds (II)"” (article draft, New York, , August 3, 1961), Box 42, File 42.4, John Wilcock 1961 file, 
Timothy Leary Papers; , Ethan Persoff and Scott Marshall, “John Wilcock: Participating in the Harvard Psilocybin Project," Boing Boing, November 21, 2013, http://boingboing.net/2013/11/21/john-wilcock-participating-in.html.

29. John Wilcock, "Blueprint for a Beautiful Community." 28.

30. Ibid.

31. Ibid.

32. Ibid., 25.

33. "If You're a Love Revolutionary, Give Us Your Support, and Come and Join Your Dharma Comrades in Developing the London Diggers' Love Commune. Let's Get in Touch as Soon as We Can.," OZ 9, page 8, February 1968, Beinecke Rare Book and Manuscript Library, Yale University, New Haven, Connecticut.

34. Recuperation in the Situationist sense of the word-radical critique stripped of its challenge and safely commodified.

35. The concepts of post-scarcity economics are most prominently associated with the later work of anarchist theorist Murray Bookchin. See Post-Scarcity Anarchism (San Francisco: Ramparts, 1971).

36. Raymond Douglas Davies, "Mr. Churchill Says," on the Kinks, Arthur (Or the Decline and Fall of the British Empire), LP (London: Pye Records, 1969).

37. Richard Neville, Hippie Hippie Shake. 1.

38. Ibid.; ellipses original.

39. Peter Coyote, Sleeping Where I Fall (Washington, D.C.: Counterpoint, 1999). 160.

40. Grateful Dead Dead.net," Shows by Year, n.d., www.dead.net. Consulted on November 6, 2019.

41. Peter Coyote, Sleeping Where I Fall, 1999. 160.

42. Dennis McNally, A Long Strange Trip: An Inside History of the Grateful Dead (New York, NY: Broadway Books, 2002). 282.

43. Peter Coyote, Sleeping Where I Fall. 160-161.

44. Ibid.

45. Grogan wrote in his memoir Ringolevio: A Life Played for Keeps (Boston: Little, Brown, 1972) that this meeting took place. Because of the explicit playing with historical reality that Grogan does in that text, I was dubious of the veracity of his claim until finding the book with Debord's signature in Grogan's papers at the New York Public Library. "The Decline and Fall of the 'Spectacular Commodity-Economy," Supplement to No. 10 of the Internationale Situationiste, (December, 1965) Emmett Grogan Papers, The Henry W. and Albert A. Berg Collection of English and American Literature, The New York Public Library, Astor, Lenox, and Tilden Foundations. New York, New York.

46. Letter to the editor included in Tom McDonough, ed.,, The Situationists and the City (New York: Verso, 2009). 52.

47. John Campbell McMillian, "You Didn't Have to Be There," 6.

48. Hakim Bey, T.A.Z.: The Temporary Autonomous Zone, Ontological Anarchy, Poetic Terrorism. (Brooklyn, NY: Autonomedia, 1991).

49. For example, see Guy Debord, The Society of the Spectacle (Detroit: Black \& Red, 1970, English translation).

50. Gitlin, The Sixties; Frank, Conquest of Cool.

51. Thomas Frank, What's the Matter with Kansas: How Conservatives Won the Heart of America (New York: Metropolitan Books, 2004).

52. Chris Hedges, Empire of Illusion: The End of Literature and the Triumph of the Spectacle (New York: Nation Books, 2009). 


\section{ABSTRACTS}

How can we resist the spectacle? This history explores actors and activists who found tools in avant-garde theatre and the underground press, drawing on the shared bonds of culture to resist the pacifying effects of the spectacle and turn it against itself. From the San Francisco Diggers, the theory and techniques of transforming passive spectators into political life actors were carried to England though the pages of popular reporting on the counterculture. Like a Trojan horse in popular culture, these techniques for activism were smuggled under what appeared to be a passive, voyeuristic gaze upon youth culture. In England, the Diggers and their ideas were embraced and celebrated by OZ Magazine and the burgeoning London hippie scene. This led to the founding of the Hyde Park Diggers and a return to England of a radical participatory call to action and a movement away from passive spectatorship. In the reservoir of English radical folk history and the contemporary innovations of avant-garde performance arts was found a powerful technique for resisting becoming a society of mere spectators.

\section{INDEX}

Keywords: Counterculture, spectacle, transnational, popular culture

\section{AUTHOR}

\section{ANDREW HANNON}

Andrew Hannon lectures in Labor Studies at the University of Massachusetts-Boston, and his research focuses on politics and power in the American counterculture and the New Left. His most recent publication is "Hippie is a Transnational Identity: Australian and American Countercultures and the London OZ," which appeared in 2016 in the Australasian Journal of American Studies. 